\title{
Exploring University Students' Preferences towards Written Corrective Feedback in EFL Context in Libya
}

\author{
Khalil Jahbel $^{1,2, *}$, Mohammad Adnan Latief ${ }^{1}$, Bambang Yudi Cahyono $^{1}$, Saleh Nuri Abdalla ${ }^{3}$ \\ ${ }^{1}$ English Department, Universitas Negeri Malang, East Java, Indonesia \\ ${ }^{2}$ Faculty of Languages, Azzaytuna University, Tarhuna, Libya \\ ${ }^{3}$ English Department, Faculty of Languages, Azzaytuna University, Tarhuna, Libya
}

Received August 19, 2020; Revised October 29, 2020; Accepted November 11, 2020

\begin{abstract}
Cite This Paper in the following Citation Styles
(a): [1] Khalil Jahbel, Mohammad Adnan Latief, Bambang Yudi Cahyono, Saleh Nuri Abdalla , "Exploring University Students' Preferences towards Written Corrective Feedback in EFL Context in Libya," Universal Journal of Educational Research, Vol. 8, No. 12A, pp. 7775 - 7782, 2020. DOI: 10.13189/ujer.2020.082565.
\end{abstract}

(b): Khalil Jahbel, Mohammad Adnan Latief, Bambang Yudi Cahyono, Saleh Nuri Abdalla (2020). Exploring University Students' Preferences towards Written Corrective Feedback in EFL Context in Libya. Universal Journal of Educational Research, 8(12A), 7775 - 7782. DOI: 10.13189/ujer.2020.082565.

Copyright $\bigcirc 2020$ by authors, all rights reserved. Authors agree that this article remains permanently open access under the terms of the Creative Commons Attribution License 4.0 International License

\begin{abstract}
This study was designed to explore Libyan EFL students' written corrective feedback preferences regarding their gender to explore the relationship between their gender and their preferences. The data were collected by applying a quantitative method by using a questionnaire. The main objective of this study was to investigate students' preferences on six types of Written Corrective Feedback and investigate which of these types they preferred the most. The researcher administered the questionnaire to a sample of $35 \mathrm{EFL}$ students (16 males and 19 females) studying English (EFL) at Azzaytuna University in Libya. The data were analyzed to reveal the frequency, percentage, mean, and standard deviation values. Paired T-test samples were used to examine the gender differences regarding the types of feedback preferences. These results revealed that students had high preferences towards writing corrective feedback in all types. The results also revealed that there were no statistically significant differences between males and females related to their choices of corrective feedback types. In addition, the results demonstrated that form feedback is the most preferred type among students, followed by unfocused feedback, while content feedback is considered as the least preferable type. This study can be regarded as one of the aspects that may contribute to the improvement in the field of education, as it attempts to explore the characteristic and kinds of error feedback strategies which may promote EFL students at universities and colleges in Libya.
\end{abstract}

Keywords Preferences, Written Corrective Feedback, EFL Undergraduate Students, Error Correction, Gender

\section{Introduction}

Written Corrective Feedback (WCF) in second language acquisition (SLA) is being the most questionable issue for decades [1]. Researchers confirmed that corrective feedback helps students to improve their L2 writing skills [2-3], while others claimed that WCF is not helpful [3] and leads to anxiety [4]. Researchers such as Lee [5] stated that students should avoid focusing on corrective feedback in writing and do not trust in the long-term effect of corrective feedback. They think that corrective feedback is a critical and non-negotiable aspect of writing instruction. Lee [5] suggested that devoting much time to providing WCF on technical mistakes in learner's essays is filled with difficulties for both teachers and students. However, Chen \& Nassaji [6] declare that corrective feedback is a fundamental aspect of L2 process. Instructors should pay attention to what learners prefer. The more instructors focus on learners' preferences to WCF, the more positively they will react to the correction.

Several studies have been performed to explore preferences for error correction types, but the results are still alarming. According to Chen \& Nassaji [7], students, 
in general, prefer the feedback that locates and clarifies the description the error, and provides the correct form of the error. Furthermore, it can be believed that learners' preferences on specific kinds and the amount of feedback impact the utilizing of it in acquiring another language. For example, if some students prefer specific types of feedback and they think they are useful for them, they may pay more attention to the effects of the corrections gained from teachers [8]. In this perspective, understanding students' preferences is very vital in learning writing skills. Referring to a study conducted by [9], teachers need to recognize that learners have various choices for the type of feedback they prefer when correcting their errors. Regarding students' preferences to six kinds of feedback (implicit, explicit, selective, comprehensive, form, content), Aridah et al. [10] suggested learners prefer to receive more feedback on grammar rather than on other topics. Results from a study by [11] to examine learners' preferences regarding written corrective types, suggest that all students like having errors corrected indirectly with the use of codes. Additionally, Chen et al. [12] carried out a study to test learners' preferences towards written error correction, however, the findings showed learners like to get feedback on content.

A similar study conducted by [13] suggests that students have less trust in content feedback than on form feedback. On the contrary, Sheppard's study [14] revealed that responding to content may lead to an improvement in grammatical accuracy, rather than using form feedback. These feedback preferences suggest that students pay more attention and appreciate teacher's feedback as a way of improving their writing accuracy.

In summary, students' preferences for the kind of feedback they obtain are essential because this may help them to incorporate this feedback into their writing works. On the other hand, if they don't prefer any type of error correction they get from their teachers that may lead to a repetition of the same errors. Chen \& Nassaji [6] declared that corrective feedback techniques are essential factors of L2 teaching and learning process. Therefore, teachers have to focus more on what students prefer. As more teachers consider their students' preferences regarding $\mathrm{WCF}$, as more positively they will react to the correction. Further study is required to explore in detail the impact of these preferences on learners' ability to develop their writing.

None of those studies looked at students' preferences on six types of written feedback considering the gender differences, especially in Libyan context. Accordingly, the present study addressed the following three study questions: 1- What types of written corrective feedback do EFL Students prefer the most? 2- Is there a relationship among types of written corrective feedback? 3- Is there any significant difference between EFL students' preferences with a different gender to their preferences to teachers' corrective feedback?

\section{Written Error Correction}

Discussing written error correction covers Typology of WCF, The Importance of Feedback, Students' Preferences, and Factors Affecting WCF

\subsection{Typology of WCF}

Corrective Feedback (CF) is a type of error correction process used by teachers to treat students' misuse of the target language [7]. However, the purpose is to fill in the gap between what students understand at the time of learning and what is aimed to be finally understood [15]. Furthermore, according to [16], WCF indicates several feedback techniques that teachers use in error correction. However, when students encounter challenges in correcting their errors, they seek the teachers' correction. In this case, teachers should recognize Written Corrective Feedback (WCF) techniques.

In the writing classroom, there are many ways to correct students' errors. In this aspect, Ellis [17] suggests a clear classification of how teachers can deal with writing errors. Besides, he classifies the kinds of written corrective feedback into six forms or strategies that he named the categorization of written corrective feedback: (a) explicit feedback (b) indirect feedback (c) metalinguistic feedback (d) selective/comprehensive feedback (e) electronic feedback, and (f) reformulation. In this study, the forms of feedback were investigated; 1: Explicit CF, where the instructor provides the students with the correct form, 2: implicit CF, where the teacher draws learners' attention to the locations of their errors without providing corrections, 3:selective CF, where the teacher chooses specific types of errors and ignores the rest, 4: Unfocused $\mathrm{CF}$, where the teacher corrects all the errors in students' paper which is also called an pervasive correction because it responds to several kinds of errors, 5: Form CF), where the teacher corrects the use of grammar, spelling, punctuation, and capitalization and 6: Content $\mathrm{CF}$ ), where the teacher focuses on ideas, coherence, and organization.

\subsection{The Importance of Corrective Feedback}

The current study focuses on the role of feedback in developing FL writing accuracy in university students to determine the kind of feedback that is more helpful in terms of developing writing accuracy, and also to see the relation of gender on students' preferences. Many studies have tested the importance of written error correction on students' writing. The debate on the efficacy of corrective feedback in L2 writing was started in 1996 by [3] who suggested that teachers should avoid Grammar Correction in written works and he attributed that to its potentially 
harmful impacts. Supporting Truscott's, a study conducted by [4] argues that overcorrecting students' written works may lead to anxiety, and make teachers spare a lot of their time on correction. Some studies also examined the interaction between the effects of error correction with learner variables, such as [18] study which indicated that learners outperformed validating WCF as a practical technique which can be utilized in EFL classes. In addition, WCF types should be considered as an essential method for improving the writing skill of EFL students. In particular, the role of feedback in correcting L2 learners' written errors has been the subject of an extensive argument in the second language acquisition literature.

The findings of a study conducted by [19] focusing on different kinds of feedback and their influence on student writing suggest that feedback plays a significant role in learning and teaching a foreign language. A similar study carried out by [20] stated that providing WCF contributes to the accuracy of learners' writings. In particular, the results suggest that explicit feedback might accomplish greater influence on learners' writing accuracy, whereas several kinds of feedback are more likely to produce rather a long-term development and/or learning over time. Therefore, Katayama [21] suggests that utilizing WCF in error correction should meet students' expectations. As a consequence, students can correct their errors and benefit from the correction strategies applied by teachers.

\subsection{Students' Preferences}

Students' preferences on written corrective feedback types (WCF) have been investigated in past and recent literature. However, since the arguments on the efficiency of preferences to written error feedback haven't been concluded, studying written feedback preferences is vital due to its significant performance in leading, inspiring, and promoting learners to enhance their accuracy in the second language (L2) writing. Consequently, students' and teachers' preferences to error correction techniques are considered as an essential factor.

Several past studies have suggested that L2 writing students value and prefer teacher feedback for developing their writing accuracy. Lee [22] claims that students are keen to receive teachers' feedback on their writing and think that they benefit from it and they rely on teachers' error corrections to develop their writing accuracy. Ferris $\&$ Roberts [11] suggest that responding to students' writing errors is a crucial part of any writing course. According to [23], investigating preferences is significant due to the reality that, when students know well what incapacitate and/or promote their acquiring the language, this understanding may impact their preferences (p.753). A similar study performed by [24] supports the consideration of students' cognitive and preferences. Thus, identification into students' preferences could be an inspiring outset point for instructors to approach better instruction.

\subsection{Factors Affecting WCF}

Exploring preferences of male and female students for WCF may assist teachers to recognize their students' expectations. Male and female students' preferences regarding WCF should be investigated more to know the detailed differences among students' preferences. In this aspect, understanding the detailed preferences between male and female students can assist teachers to give the appropriate kind of feedback that may contribute to students' second language acquisition [25]. Also, language teachers should discover students' preferences for the specific types of WCF techniques and then can implement the results to correct the students' errors. However, Russel \& Spada [16] suggest several factors that may impact selecting certain types of corrective feedback. These factors include different domains such as feedback kinds, the amount of feedback, the source of feedback, students' level of proficiency, motivation and anxiety, learner's age, and gender.

As illustrated by [26], students' preferences to WCF techniques may be affected by individual and situational characteristics. In particular, one of these elements that impact the choice of corrective feedback is gender. However, different preferences may result from the difference in gender. Sabarun [27] conducted a study to investigate the impact of the kinds of WCF on EFL students' writing performance including gender factor, showing that there was a statistically different impact for the kinds of WCF on the learners' writing performance. Meanwhile, there were no differences between gender to the learners' writing performance. A study performed by [28] to investigate whether specific types of feedback can cause any differential effects between female and male EFL learners, shows that gender does not cause a significant difference over the effectiveness of specific types of feedback. On the contrary, Al-Said [29] suggests that learners' preferences on WCF are not affected by their gender. In this regard, [30] findings revealed that males have less tendency for error correction than females.

To conclude, to maximize feedback effect on students' preferences, teachers should take into consideration learners' factors such as gender. Up to the researcher's knowledge, no study has investigated the impact of gender on different aspects of learners' preferences for corrective feedback in Libya. As a result, this study examines learners' preferences for corrective feedback including six feedback techniques to see students' preferences to written corrective feedback by considering the gender factor(male $\&$ female), because different students' gender might have different preferences.

\section{Method}

To answer the research questions, this research uses a quantitative survey, collecting demographic data and 
preferences towards WCF. The research questions of the study were answered through descriptive and inferential statistical analysis using SPSS software.

\subsection{Participants}

This study was performed at the English Department in the Undergraduate Program at the Faculty of Languages of Azzaytuna University in Libya in the academic year 2018-2019. 35 EFL undergraduate students majoring in the English language were surveyed by using a questionnaire.

\subsection{Instruments}

The researcher used one adopted survey questionnaire for collecting quantitative data for the current study. The instrument was adopted from [31] due to the similar nature of the study conducted by them and the current study. The questionnaire utilized in this paper is a closed-ended questionnaire that contains 24 items on a 5-point Likert scale. Students were allowed to choose one answer from five alternative answers provided on the questionnaire. The questionnaire consists of two parts. The first part was about demographic information, the second part was about students' preferences on types of written feedback, requiring them to rank their preferences on a scale of 1 to 5 . The questionnaire was exposed to One expert and specialist in this field. He validated the instrument before it was distributed to the students as a means of collecting data. The frequency, percentage, mean, and standard deviation values were calculated, and paired samples t-test was used to decide if there existed a relationship between student feedback preferences and their gender.

The initial reliability test shows that the dimension of some types of feedback has an alpha Cronbach value lower than 0.6 , so it has medium reliability level. To increase the level of reliability, four items $(3,9,14,19)$ were dropped. However, after the omission of these items, it can be explained that all items as a measure of the observed variables are reliable (M.7.22) since the Cronbach alpha value of the tested variables has a larger SIA (Standardized Item Alpha) of the allowed value of reliability that is 0.6.

\section{Findings}

The findings reported here cover Students' preferences towards WCF, The relationship among types of written corrective feedback, Students' gender effects on their preferences for corrective feedback

\subsection{Students' Preferences towards WCF}

Table 1 displays the descriptive statistics of the Libyan English major students' preferences on WTC in an EFL context.
Table 1. Descriptive Statistics

\begin{tabular}{|c|c|c|}
\hline Variables & Mean & SD \\
\hline Focused feedback & 3.53 & 0.78 \\
\hline Unfocused feedback & 3.85 & 0.55 \\
\hline Indirect feedback & 3.70 & 0.64 \\
\hline Direct feedback & 3.65 & 0.60 \\
\hline Content feedback & 3.27 & 0.70 \\
\hline Form feedback & 4.07 & 0.68 \\
\hline Overall feedback & 3.71 & 0.44 \\
\hline
\end{tabular}

Table 1 illustrates the variables that showed the participants' degree of preferences towards writing corrective feedback variables. The table presents the mean score and the standard deviation of students' preferences. However, according to the mean scores, form feedback (4.07/0.68), is the most preferred type among students, followed by unfocused feedback (3.85/0.55), while content feedback (3.27/0.70) is considered as their least preferable type. In addition, the table shows the mean score and the standard deviation of students' degree of preferences to the other three types of feedback respectively as follows: indirect feedback (3.70/0.64), direct feedback (3.65/0.60), and focused feedback (3.53/0.78). The total mean score for the six domains was (3.71) and the standard deviation was (0.44).

\subsection{The Relationship between Kinds of Written Corrective Feedback}

The findings reveal that the unfocused feedback variable is significantly and positively correlated with the focused feedback $(r=.363, p<.05)$, however, the result of variables indirect, direct, content, and form did not show any significant relationship with focused feedback. Unfocused feedback shows a significant positive relationship with indirect, direct, and form feedback $(r=.531, .398, .497$, $\mathrm{p}<.05$ and $\mathrm{p}<.01)$ respectively. Indirect feedback shows a significant positive relationship with direct and form feedback $(\mathrm{r}=.389$ and $.452, \mathrm{P}<.01)$ respectively, indirect did not show a significant correlation with content feedback (See Table 2)

Table 2. Correlation between WCF sub-variables

\begin{tabular}{|c|c|c|c|c|c|c|}
\hline Variables & 1 & 2 & 3 & 4 & 5 & 6 \\
\hline $\begin{array}{l}\text { Focused } \\
\text { feedback }\end{array}$ & & & & & & \\
\hline $\begin{array}{l}\text { Unfocused } \\
\text { feedback }\end{array}$ & $.363^{*}$ & & & & & \\
\hline $\begin{array}{l}\text { Indirect } \\
\text { feedback }\end{array}$ & .060 & $.531 * *$ & & & & \\
\hline $\begin{array}{c}\text { Direct } \\
\text { feedback }\end{array}$ & .249 & $.398^{*}$ & $.389^{* *}$ & & & \\
\hline $\begin{array}{l}\text { Content } \\
\text { feedback }\end{array}$ & .141 & .266 & .266 & .251 & & \\
\hline $\begin{array}{c}\text { Form } \\
\text { feedback }\end{array}$ & .274 & $.497 * *$ & $.452 * *$ & $.463^{* *}$ & $.451^{* * *}$ & \\
\hline
\end{tabular}




\subsection{Students' Gender Effects on Their Preferences for Corrective Feedback}

To explore the gender differences in students' preferences to six types of WCF, a sample t-test was implemented to compare between the EFL male and female students' preferences to WCF. (See Table 3)

Table 3. The findings of the sample t-test

\begin{tabular}{|c|c|c|c|c|c|}
\hline \multicolumn{6}{|c|}{ Group Statistics } \\
\hline \multirow{3}{*}{$\begin{array}{c}\text { Total } \\
\text { WCF }\end{array}$} & Gender & N & Mean & $\begin{array}{c}\text { Std. } \\
\text { Deviation }\end{array}$ & $\begin{array}{c}\text { Std. Error } \\
\text { Mean }\end{array}$ \\
\cline { 2 - 6 } & Male & 16 & 3.6726 & .47360 & .11840 \\
\cline { 2 - 6 } & Female & 19 & 3.7444 & .43736 & .10034 \\
\hline
\end{tabular}

Table 3 indicates that both male and female learners value written corrective feedback. Since the M-value is less than .05 , the results of paired samples T-test analysis shows that there are no statistically significant differences between male and female students in their preferences for the six types of WCF (respectively:.11840/.10034). The data reveal the mean of the male group (M 3.6726/.47360) and female group (M 3.7444/.43736).

\section{Discussion}

One of the purposes of the current study is to boost some past similar researches by carrying out a study on learner preferences in a different background at Azzaytuna University in Libya. This question asked students about their preferences for six categories of corrective feedback, namely, indirect, direct, focused, unfocused, content, and form feedback. Regarding students' preferences for the six types of WCF, the current results reveal that there are different preferences between male and female students.

\subsection{EFL Students' Preferences towards the Writing Corrective Feedback}

To investigate students' preferences for selecting the most preferred technique of written corrective feedback, the mean score for each type was determined. The findings of the research show that a large number of the learners value the corrective feedback on Form Feedback (M. 4.07) as the most preferred type, followed by unfocused feedback (M. 3.85) as the second preferred type. These results match the study by [10] who suggest that learners prefer to receive more feedback on grammar rather than on other topics. Conversely, learners' preferences are opposed to previous research conducted by [32] which suggested that Form Feedback was less effective on students' writing. Those who prefer form feedback think that it is useful in assisting them enhancing the writing ability and accuracy. Whereas, the findings regarding unfocused feedback are in line with [33] who suggest that students prefer teachers to use the unfocused technique. On the contrary, these findings differ from those of [34] as the participants did not prefer this technique.

The justification for preferring this type could be attributed to the students' worries that their grammatical competence was not strong enough to allow them to mark their grammatical errors if their teachers don't mark them. The results also suggest that learners' most preferred type of feedback is indirect technique (M 3.70), followed by direct (M 3.65) WCF. The results are consistent with the results of previous researches, that have achieved similar results. For example, results from a study by [35] show that students preferred direct feedback. The justifications for preferring direct feedback is that they valued accuracy and they were most concerned with whether their errors were corrected and wanted to understand the type of their errors. On the other hand, preferring direct feedback is inconsistent with [36] that direct feedback is less effective in developing students' writing accuracy. Regarding indirect feedback, the findings of the study are congruent with [37] that learners in implicit technique considerably outperformed those in direct groups.

On the contrary, these results are different from [38] findings that learners do not value indirect feedback. However, the application of these two types of WCF could encourage students to recognize and manage their writing errors. The findings also demonstrate that students' less preferred feedback is Content Feedback (M 3.27), followed by Focused Feedback (M 3.53). These results matched those of one similar study by [13] suggested that students have less trust on content feedback than that on form feedback. On the contrary, [14] findings revealed that responding to content feedback may lead to improvement in grammatical accuracy. Regarding focused feedback, the findings are in line with [39] findings, that students prefer using focused error correction as it may lead to improving learners' efficiency in writing articles. Furthermore, the findings contradict [40] findings, that most students do not prefer their teachers to apply this type because they think they will not be able to do the correction alone without the help of teachers, consequently, they may repeat the same errors in their future writings. To conclude, these feedback preferences suggest that students pay more attention and appreciate teachers' feedback as a way of improving their writing accuracy.

\subsection{The Relationship among Types of the Writing Corrective Feedback}

To investigate whether there is a correlation between six different types of corrective feedback, paired samples T-test was implemented. The mean difference is considerable at the level of 0.05 . The statistically considerable differences will occur when the Sig value is greater than 0.05 . The findings show that there is considerable connection between unfocused and focused feedback. Besides, there is also a statistically considerable 
relation between unfocused feedback and implicit, direct, and form corrective feedback. Additionally, there is a relation between indirect and direct and form feedback, whereas there is no significant relationship between focused feedback and indirect, direct, content, and form feedback. In addition, there is also no statistically significant relationship between indirect and content feedback.

\subsection{The Correlation between EFL Students with Different Gender to Their Preferences to Teachers' Corrective Feedback}

Providing corrective feedback could be influenced by some factors. These factors may include students' expectations, motivation, age, and gender. However, students' preferences regarding WCF should be investigated more considering their gender. To check the influence of gender on students' preferences on six types of corrective feedback, paired samples T-test was applied. The findings of paired samples T-test analysis demonstrated that there was no statistically important discrepancy between male and female learners in their preferences for the six types of WCF. These findings are consistent with a study performed by [28] the results displayed that gender does not lead to any important discrepancy over efficiency of specific types of feedback. On contrary, the findings are not in the same vein with [27] findings that there was a statistically different impact for the kinds of WCF on the students' writing achievement. The researcher suggests that teachers should take into consideration learners' factors such as gender, because teachers may replace the kind and amount of feedback based on some factors like gender. However, without considering the affective factors, students may be provided a type of WCF that they don't prefer or don't benefit from it.

\section{Conclusions}

The study focused on six types of written CF (focused, unfocused, direct, indirect, content, and form written $\mathrm{CF}$ ), and explored Azzaytuna EFL students' preferences for teachers' correction and to test the impact of gender on selecting types of WCF. Concerning the first research question, the findings indicate that the students' most preferred type of corrective feedback was form feedback. Whereas, the less frequent type for both male and female students is content feedback. About the second study question, a sample t-test analysis was performed to investigate the effect of gender on selecting type of WCF. Results indicate that there is no statistical important discrepancy between both genders (males \&females). The third study question was to see if there is a relationship between types of feedback. The findings demonstrate there is a statistically important relation among some kinds of corrective feedback, but no significant relationship between other types. The study brought in vital findings regarding the impact of gender on selecting specific types of feedback. However, this study could be considered as a novelty in the sense that it is the first study that has been conducted in this context addressing the impact of gender. From the instructive angle, the study may contribute to the current understanding of how students' preferences involving the gender affect the accuracy of writing.

\section{Acknowledgement}

This work was financially supported by a Ph.D. Scholarship (for the first author) from the Ministry of Higher Education of Libya State for KJ.

\section{REFERENCES}

[1] Nemati, M., Alavi, S. M., Mohebbi, H. \& Masjedlou, A. P. Speaking out behalf of the voiceless learners: Written corrective feedback for English in Iran. Issues in Educational Research, 27(4), 822-841. (2017). ISSN: 1837-6290.

[2] Hartshorn, K. J., Evans, N. W., Merrill, P. F., Sudweeks, R. R., Strong-Krause, D., \& Anderson, N. J. Effects of dynamic corrective feedback on ESL writing accuracy. TESOL Quarterly, 44(1), 84-109. (2010). DOI: $10.5054 /$ tq.2010.213781.

[3] Truscott, J. The case against grammar correction in L2 writing classes. Language Learning, 46(2), 327-369. (1996). https://DOI.org/10.1111/j.1467-1770.1996.tb01238.x.

[4] Lee, I. ESL learners' performance in error correction in writing: Some implications for teaching. System, 25(4), 465-477.(1997).https://doi.org/10.1016/S0346-251X(97)00 045-6.

[5] Lee, I. Teacher written corrective feedback: Less is more. Language Teaching, 52(4), 524-536. (2019). DOI: https://doi.org/10.1017/S0261444819000247.

[6] Chen, S., \& Nassaji, H. Focus on form and corrective feedback research at the University of Victoria, Canada. Language Teaching, 51(2), 278-283. (2018). DOI:10.1017/S026144481800006X.

[7] Chen, S., Nassaji, H., \& Liu, Q. EFL learners' perceptions and preferences of written corrective feedback: a case study of university students from Mainland China. Asian-Pacific Journal of Second and Foreign Language Education, 1(1), 5-1-17. (2016). http://dx.DOI.org/10.1186/s40862-016-001 $0-\mathrm{y}$.

[8] Schulz, R. A. Cultural differences in student and teacher perceptions concerning the role of grammar instruction and corrective feedback. The Modern Language Journal, 85(2), 244-258. (2001).

https://DOI.org/10.1111/0026-7902.00107. 
[9] Riazi, A., \& Riasati, M. J. Language learning style preferences: A students case study of Shiraz EFL Institutes. Asian EFL Journal, 9(1), 97-125. (2007). ISSN: 1738-1460.

[10] Aridah, A., Atmowardoyo, H., \& Salija, K.Teacher practices and students' preferences for written corrective feedback and their implications on writing instruction. International Journal of English Linguistic, 7(1), 112-125. (2017). DOI: 10.5539/ijel.v7n1p112.

[11] Ferris, D., \& Roberts, B. Error feedback in L2 writing classes: How explicit does it need to be? Journal of Second Language Writing, 10(3), 161-184. (2001). https://DOI.org/ 10.1016/S1060-3743(01)00039-X.

[12] Chen, J., Lin, J., \& Jiang, L. Corrective Feedback in SLA: Theoretical Relevance and Empirical Research. English Language Teaching, 9(11), 85. (2016). DOI: 10.5539/elt.v9n11p85.

[13] Soraya, Z., \& Amel, P. B. Form-based feedback versus content-based feedback for EFL learners' academic writing development: Learners' perspectives and preferences. Social and Human Sciences Review, 18(37), 341-358. (2017).

[14] Sheppard, K. Two feedback types: Do they make a difference? RELC Journal, 23(1), 103-111. (1992). ISSN: ISSN-0033-6882.

[15] Hattie, J., \& Timperley, H. The power of feedback. Medical Education, 77(1), 81-112. (2007). DOI: 10.3102/00346543 0298487.

[16] Russel, J., \& Spada, N. The effectiveness of corrective feedback for the acquisition of L2 grammar:A meta-analysis of the research. In Synthesizing research on language learning and teaching (pp. 131-164). Amsterdam, Netherlands:John Benjamins Publishing Co. (2006).

[17] Ellis, R. A typology of written corrective feedback types. ELT Journal, 63(2), 97-107. (2009). https://DOI.org/10.109 3/elt/ccn023.

[18] Aghajanloo, K. The effect of teachers' written corrective feedback (WCF) Types on intermediate EFL learners' writing performance. Advances in Language and Literary Studies, 7(3), $x x$-xx. (2016). Doi:10.7575/aiac.alls.v.7n.3p.2 8.

[19] Kamberi, L. The significance of teacher feedback in EFL writing for tertiary level foreign language learners. Procedia - Social and Behavioral Sciences, 70(2008), 1686-1690. (2013). DOI: 10.1016/j.sbspro.2013.01.241.

[20] Farjadnasab, A., \& Khodashenas, M. The effect of written corrective feedback on EFL students' writing accuracy. International Journal of Research in English Education, 2(2), 30-42. (2017). DOI: 10.18869/acadpub.ijree.2.2.30.

[21] Katayama, A. Japanese EFL students' preferences toward correction of classroom oral errors. Asian EFL Journal, 9(4), 289-305. (2007). ISSN: 1738-1460.

[22] Lee, I. Error correction in L2 secondary writing classrooms: The case of Hong Kong. Journal of Second Language Writing, 13(4), 285-312. (2004). DOI:10.1016/j.jslw.2004.0 8.001 .

[23] Birenbaum, M. Assessment and instruction preferences and their relationship with test anxiety and learning strategies. Higher Education, 53(6), 749-768. (2007). https://DOI.org/ $10.1007 / \mathrm{s} 10734-005-4843-4$.

[24] Zhang, Y., Zhang, L. \& Ma, L. A Brief Analysis of corrective feedback in oral interaction. Journal of Language Teaching and Research, 1(3), 306-308. (2010). DOI:10.4304/jltr.1.3.306-308.

[25] Amalia, Z. D. H., Fauziati, E., \& Marmanto, S. Male and female students' preferences on the oral corrective feedback in English as Foregin Language (EFL) speaking classroom. Humaniora, 10(1), 25-33. (2019). https://DOI.org/10.23971 /jefl.v9i1.1047.

[26] Havnes, A., Simth, K., Dysthe, O., \& Ludvisgen, K. Formative assessment and feedback: Making learning visible. Studies in Educational Evaluation, 38(1), 21-27. (2012). http://dx.doi.org/10.1016/j.stueduc.2012.04.001.

[27] Sabarun. Effect of gender and the types of written corrective feedback on the L2 learners' writing performance. The 3rd English Language and Literature International Conference (ELLiC) Proceedings). (2019). Electronic ISSN: 2579-7263.

[28] Araghi, S. M., \& Sahebkheir, F.The effect of focused versus unfocused corrective feedback on developing grammatical accuracy of Iranian EFL learners' written performance within different gender groups. Indian Journal of Fundamental and Applied Life Sciences, 4(3), 720-729. (2014). ISSN: 2231- 6345 (Online).

[29] Al-Said, M. F. Responses to learners' writing in EFL at Sultan Qaboos University: A Case of Teachers' and Students' Beliefs (Master's thesis). Sultan Qaboos University, Sultanate of Oman. (1996).

[30] Zarei, N. The relationship between age and corrective feedback in oral communication strongly disagree. Online Journal of ICT for Language Learning "5th edition". International conference. (2011).

[31] Mohammedi, N. A, A. Exploring the perceived and the actual written feedback preferences between ELF students and teachers in UAE. Thesis submitted to the United Arab Emirates University. (2016). https://scholarworks.uaeu.ac.a e/all_theses/470.

[32] Truscott, J. The case for "the case against grammar correction in L2 writing classes": A Response to Ferris. Journal of Second Language Writing,8(2), 111-122. (1999). https:// DOI.org/10.1016/S1060-3743(99)80124-6.

[33] Hajian, L., Shirazi, Ali A., \& Ahmadi, F. M. Study of students' and teachers preferences and attitudes towards correction of classroom written errors in Iranian EFL context. International Journal of Applied Linguistics \& English Literature, 3(5), p. 287. (2014).

DOI:10.7575/aiac.ijalel.v.3n.5p.287.

[34] Farrokhi, F., and Sattarpour, S. The effects of focused and unfocused written Corrective feedback on grammatical accuracy of Iranian EFL learners. Theory and Practice in Language Studies, 1(12), 1797-1803. (2011). DOI:10.4304/tpls.1.12.1797-1803.

[35] Black, D., \& Nanni, A.Written corrective feedback: Preferences and Justifications of teachers and students in a Thai context. GEMA Online Journal of Language Studies, 
16(3), 99-114. (2016). DOI: 10.17576/gema-2016-1603-07.

[36] Suyoga, D., \& Nirmala, T. The impact of direct feedback on students' EFL writing skill: A case study on Writing III course in STKIP Suar Bangli. Journal of Psychology and Instruction, 1(3), 137-141. (2017). DOI: http://dx.DOI.org/ 10.23887/jpai.v1i3.12575.

[37] Talatifard, S.The effect of reactive focused corrective feedback on Iranian EFL learners' writing performance. Journal of Advances in English Language Teaching, 4(3), 40-48. (2016). ISSN 1805-8957.
[38] Zhang, L., \& Zheng, Y. Feedback as an assessment for learning tool: How useful can it be? Assessment \& Evaluation in Higher Education,43(7),1120-1132. (2018). https://DOI.org/10.1080/02602938.2018.1434481.

[39] Sheen, Y. The effect of focused written corrective feedback and language aptitude on ESL learners' acquisition of articles. TESOL Quarterly, 41(2), 255-283. (2007). http://dx.DOI.org/10.1002/j.1545-7249.2007.tb00059.x.

[40] Bitchener, J., \& Ferris, D. R. Written corrective feedback in second language acquisition. London: Routledge. (2012). https://DOI.org/10.4324/9780203832400. 